\title{
THE EFFECTS OF ERYTHRITOL, FSH AND FEMALE GONADAL HORMONES ON THE GROWTH IN VITRO OF VIBRIO FETUS VAR. VENEREALIS*
}

\author{
A. F. WALSH, $\uparrow$ F. H. WHITE AND A. C. WARNICK \\ Department of Veterinary Science, University of Florida, \\ Gainesville, Florida 32601, U.S.A.
}

(Received 7th February 1972)

\begin{abstract}
Summary. No increase in the growth rate of Vibrio fetus var. venerealis was observed in a series of growth trials in which different concentrations of erythritol, FSH, oestrone and progesterone were added to liquid culture medium. A significant increase in the growth rate was observed $(P<0.05)$ when inverse concentrations of oestrone and progesterone were incorporated into the same medium with concentrations of oestrone being higher than those of progesterone.
\end{abstract}

\section{INTRODUGTION}

The presence of potential substrates for bacteria in the lumen of the reproductive tract of the cow was reported by Olds \& VanDemark (1957). Hawk, Simon, Cohen, McNutt \& Casida (1955) noted an apparent hormonal regulation of the uterine bacterial defence mechanism. A study of the enhanced response in vitro of $V$. fetus to separate additions of progesterone, corpus luteum extract or testosterone to thioglycollate broth led Osborne \& Bourdeau (1955) to suggest a possible hormonal influence on the course of $V$. fetus infection in the cow. Stimulation of the growth in vitro of $V$. fetus in the presence of 17- $\beta$ oestradiol $(0 \cdot 005 \%)$ was described by Zemjanis \& Hoyt (1960).

The presence of erythritol in uterine tissues and fluids of the cow was described by Keppie, Williams, Witt \& Smith (1965), not only as a factor in the tissue localization of the Brucellae, but also as a growth factor for these organisms. The possibility of erythritol as a growth factor for $V$. fetus was suggested by $\mathbf{M}$. Herzberg (personal communication, 1966). However, erythritol failed to stimulate the growth in vitro of $V$. fetus var. intestinalis and apparently is not involved in the tissue localization of this organism (Lowrie \& Pearce, 1970).

The present study was undertaken to determine the response in vitro of $V$. fetus var. venerealis to different concentrations of erythritol, FSH, oestrone and progesterone when individually added to a basal medium. The combined Series.

* This paper is published as No. 4307 in the Florida Agricultural Experiment Stations Journal

$\dagger$ Present address: Department of Microbiology, Orange Memorial Hospital, Orlando, Florida 32806, U.S.A. 
effects of inverse concentrations of oestrone and progesterone on the growth of $V$. fetus var. venerealis were also considered.

\section{MATERIALS AND METHODS}

Vibrio isolant

The organism used was a smooth fresh isolant of $V$. fetus var. venerealis previously identified by the criteria of Florent (1963) and Lecce (1958). To avoid the use of repeated subcultures of the isolant, 24- to 48-hr-old cultures in Brucella broth (Pfizer Diagnostic Division, New York) were stored at $-70^{\circ} \mathrm{C}$. These cultures were used to develop primary inocula.

Basal medium for growth

Brucella broth was used for each trial. Brucella broth with $0.16 \%$ agar added was used to prepare seed inocula for the tests. All media were sterilized at $121^{\circ} \mathrm{C}$ for $15 \mathrm{~min}$. All cultures were incubated at $37^{\circ} \mathrm{C}$.

Gas atmosphere required for growth

The cultures in test and control nepheloflasks were incubated in an atmosphere of $10 \% \mathrm{CO}_{2}, 85 \% \mathrm{~N}_{2}$ and $5 \% \mathrm{O}_{2}$. The gas mixture was commercially prepared (Airco Inc., Jacksonville, Florida). It was sterilized by passage through a glass cylinder packed with glass wool. Each end of the cylinder was closed with a rubber stopper through which glass tubing was passed. A glasstipped rubber tube delivered the gas into the inoculated flask. The entire assembly was sterilized at $121^{\circ} \mathrm{C}$ for $15 \mathrm{~min}$. The gas mixture was passed into each flask for a period of $30 \mathrm{sec}$ at a flow rate of $2 \mathrm{lb} / \mathrm{in}^{2}$ and the flask was then sealed with a black rubber stopper. Seed cultures were prepared by the method described by Lovell (1964).

\section{Growth factors studied}

The growth factors studied were 1-erythritol, porcine FSH (Mann Research Laboratories Inc., New York), oestrone (1,3,5,(10)-estratrion-3-ol-17-one) and progesterone, USP (Matheson, Coleman and Bell Inc., East Rutherford, New Jersey).

\section{Preparation of test inocula}

Seed cultures of $V$. fetus were prepared in $30 \mathrm{ml}$ Brucella broth with added agar. These were propagated in a Model G Incubator-Shaker (New Brunswick Scientific Co., New Brunswick, New Jersey) at 100 oscillations/min. Each culture was checked for motility, morphology and purity after a 36-hr incubation period. The cells were synchronized by passage through five layers of sterile Whatman Number 40 filter paper. A 5-ml inoculum of broth culture was used for each trial.

\section{Trial 1. Erythritol}

Duplicate nepheloflasks of erythritol concentrations of $0 \cdot 06,1 \cdot 0,3 \cdot 0,5 \cdot 0$ and $10.0 \mathrm{mg} / \mathrm{ml}$ were prepared aseptically in Brucella broth from membrane- 
filtered (Millipore Filter Corporation, Bedford, Mass.) erythritol stock solutions of $50 \%(\mathrm{w} / \mathrm{v})$ and $3 \%(\mathrm{w} / \mathrm{v})$. A nepheloflask of Brucella broth was used as a colorimeter blank. Duplicate nepheloflasks of Brucella broth were set up as growth controls. Both test and control flasks were inoculated and the gas atmosphere was added. The optical density (OD) of each flask was read at time zero on a spectrophotometer (Bausch and Lomb Spectronic 20) at $525 \mathrm{~nm}$. All the flasks were incubated in the shaker at 100 oscillations/min. The OD was read at 2-hr intervals until the organism reached the peak of the exponential growth phase. At this time, all the cultures were examined for purity. Graphs of OD against time were recorded for each test and control flask.

\section{Trial 2. Oestrone}

Duplicate nepheloflasks of oestrone concentrations of $0.01,0.009,0.007$, $0.005,0.003,0.001$ and $0.0005 \mathrm{~g} / 100 \mathrm{ml}$ were prepared aseptically in sterile Brucella broth from a $0.4 \%(\mathrm{w} / \mathrm{v})$ stock solution of oestrone in analytical grade chloroform. Another series of flasks was similarly prepared for use as reagent blanks. Gentle steam heat was used to remove the chloroform from the broth, leaving the hormone in suspension. To assay the effect of trace amounts of chloroform on the growth of V. fetus, growth controls were prepared in chloroform-treated broth as well as in normal Brucella broth. The test and control flasks were inoculated and incubated as in Trial 1. The data were similarly collected.

\section{Trial 3. Progesterone}

A stock solution of progesterone $(0.4 \% \mathrm{w} / \mathrm{v})$ was prepared in analytical grade chloroform. The hormonal concentrations and methods were the same as those used in Trial 2.

\section{Trial 4. Combined inverse concentrations of oestrone and progesterone}

A series of three nepheloflasks was prepared for each concentration of the combined hormones. Volumes of the stock solutions used in Trials 2 and 3 were added to sterile Brucella broth to give final oestrone to progesterone concentrations of $0.001 / 0.009,0.003 / 0.007,0.005 / 0.005,0.007 / 0.003$ and $0.009 / 0.001$ $\mathrm{g} / 100 \mathrm{ml}$. Control cultures, reagent blanks and colorimeter blanks were prepared by the methods described in Trial 2. Inoculation, incubation and data collection were performed as previously described (Trial 1).

\section{Trial 5. FSH}

A stock solution of $\mathrm{FSH}(0.5 \% \mathrm{w} / \mathrm{v})$ was prepared in sterile distilled water. Hormone concentrations of $0.01,0.005,0.003,0.001$ and $0.0005 \mathrm{~g} / 100 \mathrm{ml}$ were prepared in sterile Brucella broth in triplicate. The trial was completed by the methods described in Trial 1.

\section{Data analyses}

The slopes of the growth curves and the mean change in OD per unit time were derived for each trial. The data were examined for statistical differences 
Table 1. Mean optical density changes per unit time* and mean slopes of growth curves of $V$. fetus. var. venerealis in the presence of different growth factors. OD readings taken at $525 \mathrm{~nm}$.

Trial 1. Erythritol. Unit time $16 \mathrm{hr}$

\begin{tabular}{l|l|l|l|l|l|l}
\hline Concentration $(\mathrm{mg} / \mathrm{ml})$ & 0.06 & 1.0 & 3.0 & 5.0 & 10.0 & Control \\
OD change & 0.297 & 0.359 & 0.357 & 0.375 & 0.360 & 0.386 \\
Slope mean & 1.38 & 1.69 & 1.82 & 1.75 & 1.81 & 1.86 \\
\hline
\end{tabular}

Trials 2 and 3. Oestrone and progesterone. Unit time $6 \mathrm{hr}$

\begin{tabular}{l|l|l|l|l|l|l|l|l}
\hline Concentration $(\mathrm{g} / 100 \mathrm{ml})$ & 0.01 & 0.009 & 0.007 & 0.005 & 0.003 & 0.001 & 0.0005 & Control \\
$\begin{array}{l}\text { Oestrone } \\
\text { OD change }\end{array}$ & & & & & & & & \\
Slope mean & 0.175 & 0.170 & 0.145 & 0.155 & 0.160 & 0.155 & 0.165 & 0.145 \\
Progesterone & 0.593 & 0.580 & 0.490 & 0.518 & 0.531 & 0.524 & 0.512 & 0.475 \\
OD change & & & & & & & & \\
Slope mean & 0.125 & 0.130 & 0.125 & 0.095 & 0.092 & 0.132 & 0.092 & 0.140 \\
\hline
\end{tabular}

Trial 4. Oestrone/progesterone. Unit time $4 \mathrm{hr}$

\begin{tabular}{l|l|l|l|l|l|l}
\hline Concentrations $(\mathrm{g} / 100 \mathrm{ml})$ & $0.001 /$ & $0.003 /$ & $0.005 /$ & $0.007 /$ & $0.009 /$ & Control \\
& 0.009 & 0.007 & 0.005 & 0.003 & 0.001 & \\
OD change & 0.110 & 0.120 & 0.143 & 0.130 & 0.146 & 0.103 \\
Slope mean & 0.551 & 0.617 & 0.723 & 0.702 & 0.747 & 0.530 \\
\hline
\end{tabular}

Trial 5. FSH. Unit time 2 hr

\begin{tabular}{l|l|l|l|l|l|l}
\hline Concentration $(\mathrm{g} / 100 \mathrm{ml})$ & 0.01 & 0.005 & 0.003 & 0.001 & 0.0005 & Control \\
OD change & 0.090 & 0.080 & 0.080 & 0.090 & 0.090 & 0.094 \\
Slope mean & 0.90 & 0.80 & 0.86 & 0.90 & 0.90 & 0.94 \\
\hline
\end{tabular}

* Mean optical density (OD) change per unit time represents the interval in which the greatest change in OD took place.

Table 2. Statistical analysis of the growth curve slopes of $V$. fetus var. venerealis in the presence of different growth factors

\begin{tabular}{|c|c|c|c|c|}
\hline Trial no. & $\begin{array}{c}\text { Calculated } \\
\text { F value }\end{array}$ & $\begin{array}{c}\text { Tabulated } \mathrm{F} \\
\text { value }(\mathbf{P}<0.05)\end{array}$ & Significance & $\begin{array}{c}\text { Duncan's } \\
\text { multiple range } \\
\text { test at } 0.05\end{array}$ \\
\hline $\begin{array}{l}\text { 1. Erythritol } \\
\text { 2. Oestrone } \\
\text { 3. Progesterone } \\
\text { 4. Oestrone/Progesterone }\end{array}$ & $\begin{array}{l}4 \cdot 11 \\
3 \cdot 32 \\
2 \cdot 53 \\
8 \cdot 76\end{array}$ & $\begin{array}{l}4 \cdot 39 \\
5 \cdot 19 \\
3 \cdot 50 \\
3 \cdot 11\end{array}$ & $\begin{array}{l}\text { None } \\
\text { None } \\
\text { None } \\
\text { Yes }\end{array}$ & $\begin{array}{l}\text { Not applied } \\
\text { Not applied } \\
\text { Not applied } \\
\text { Applied; see } \\
\text { text }\end{array}$ \\
\hline 5. FSH & 1.95 & $3 \cdot 11$ & None & Not applied \\
\hline
\end{tabular}


between the test and control growth curves by a one-way analysis of variance with equal replication and Duncan's multiple range test (Steel \& Torrie, 1960).

\section{RESULTS}

Mean changes in OD per unit time and the slope means for each trial are given in Table 1. The results of statistical examination of the data are given in Table 2. No significant differences $(P<0.05)$ were found between the test and control growth curves established in trials of erythritol, oestrone, progesterone and FSH.

Significant differences were found among the results of the oestrone-progesterone trial (No. 4). Samples of some hormonal concentrations were significantly different from the hormone-free controls $(P<0.05)$. No significant difference was found among concentrations of oestrone/progesterone of $0 \cdot 005 / 0 \cdot 005$, $0.007 / 0.003$ and $0.009 / 0.001 \mathrm{~g} / 100 \mathrm{ml}$, although these were significantly different from the hormone-free controls. No significant difference was determined between oestrone/progesterone concentrations of $0.001 / 0.009$ and 0.003 / $0.007 \mathrm{~g} / 100 \mathrm{ml}$ and the hormone-free controls.

All cultures were found to be pure on routine check after each trial.

The use of chloroform as a vehicle for the steroid hormones and its subsequent removal as described had no effect on the growth of $V$. fetus $\left(\right.$ calc $^{t}=1 \cdot 0$; $\left.0 \cdot 05^{\mathfrak{t}}=6 \cdot 314\right)$.

\section{DISCUSSION}

The study of bacterial growth rate based on OD rather than on the use of viable cell counts was found to be of value by Lyon, Hall \& Costas-Martinez (1970). The reliability of the OD method of growth study improves with the use of synchronized cultures (Wilson \& Miles, 1964) which allow the increase in OD of the culture to be proportional to the increase in cell numbers. This proportionality ceases to be a linear function when the OD reading exceeds 0.4 (Anon., 1957). For this reason, the slopes derived in all the trials were calculated from points obtained during the exponential growth phase at an OD of less than $0 \cdot 4$. Turbidometric studies for potential growth factors for $V$. fetus were used by Trueblood \& Tucker (1957) and Reich, Dunne, Bortree \& Hokanson (1957).

The metabolism of $V$. fetus was determined to be microaerophilic by May (1953). Alexander (1957) demonstrated a lack of fermentative ability for $V$. fetus. Biochemical and serological differences were reported between $V$. fetus var. venerealis and V. fetus var. intestinalis (Florent, 1963; Walsh \& White, 1968). These differences deserve emphasis if progress is to be made in further studies of $V$. fetus metabolism. A common feature of the metabolism of both varieties of $V$. fetus is an apparent failure to utilize most carbohydrates as substrates. Erythritol failed to stimulate the growth of $V$. fetus var. intestinalis (Lowrie \& Pearce, 1970) and the present study indicates a similar lack of activity in the metabolism of $V$. fetus var. venerealis. The possibility of erythritol as a tissue localizing factor for $V$. fetus var. venerealis in the uterus and cervix of the cow is thus rather remote. 
The growth increase due to an oestrogenic compound noted by Zemjanis \& Hoyt (1960) was not observed in this study. Not only oestrone but also progesterone and FSH were without effect. Osborne \& Bourdeau (1955) observed improved growth rates when hormone-containing tissue extracts were added to culture medium. The presence of more than one tissue localizing factor in vivo was suggested by Lowrie \& Pearce (1970). The rôle of hormones in the tissue localization of bacterial species within the female reproductive tract remains to be defined.

The results of the oestrone-progesterone assay (Trial 4) showed a significant growth increase of $V$. fetus in those concentrations of oestrogen and progesterone in which the oestrone was in the greatest concentration. Hawk et al. (1955) found that oestrogen inhibited the growth in utero of Escherichia coli, but the uterine defence mechanism appears to be less effective against $V$. fetus (Black, Simon, Kidder \& Wiltbank, 1954). In the intact animal, the combined effects of oestrogen and progesterone on the uterus are inseparable (Nalbandov, 1964). Trial 4 more closely simulated the conditions in vivo and may have provided for the hormones to act synergistically.

The use of studies in vitro to obtain a better understanding of the effects of potential substrates on the growth of $V$. fetus in the reproductive tract of the cow probably cannot duplicate similar studies in vivo. Further animal experimentation is needed to explain the extreme tissue localization of $V$. fetus var. venerealis in the reproductive tract of the cow. Such experimentation would lead to a greater understanding of $V$. fetus metabolism generally.

\section{ACKNOWLEDGMENTS}

This work was supported in part by research grant AI-07912 from the National Institute of Allergy and Infectious Diseases, and forms part of a dissertation submitted by the senior author to the Graduate Council of the University of Florida in partial fulfilment of the requirements for the Ph.D. degree.

\section{REFERENCES}

AleXander, J. K. (1957) Energy sources utilised by Vibrio fetus. F. Bact. 74, 168.

AnON. (1957) Manual of microbiological methods. Society of American Bacteriologists, Committee on Bacteriological Technique. McGraw-Hill, New York.

Black, W. G., Simon, J., KmDer, H. E. \& Wiltbank, J. N. (1954) Bactericidal activity of the uterus in the rabbit and the cow. Am. J. vet. Res. 15, 247.

Florent, A. (1963) À propos des vibrions responsable de la Vibriose génitale des bovins et des ovins. Bull. Off. int. Epizoot. 60, 1063.

Hawk, H. W., Simon, J., Cohen, H., MaNurt, S. H. \& Casida, L. E. (1955) The relative bactericidal activity of the uterine and body cavities of estrous and pseudo-pregnant rabbits. F. Am. vet. med. Ass. 126, 268.

Keppie, J., Williams, A. E., WitT, K. \& Smrth, H. (1965) The role of erythritol in the tissue localisation of Brucellae. Br. F. exp. Path. 46, 104.

LeCce, J. G. (1958) Some biochemical characteristics of Vibrio fetus and other related vibrios isolated from animals. 7. Bact. 76, 312.

Lovelt, J. E. (1964) Genital vibriosis in Iowa cattle. Iowa St. Univ. Vet. 26, 10.

Lowrie, D. B. \& PeArce, J. H. (1970) The placental localisation of Vibrio fetus. F. Microbiol. 3, 607.

Lyon, R. H., Hall, W. H. \& Costas-Martinez, G. (1970) Utilisation of amino acids during the growth of Mycobacterium tuberculosis in rotary cultures. Infec. \& Immunity, 1, 513. 
MAY, L. K. (1953) The microaerophilic nature of Vibrio fetus. M.S. thesis, Montana State College, Bozeman, Montana.

Nalbandov, A. V. (1964) Reproductive physiology, 2nd edn. Freeman, San Francisco.

Olds, D. \& VanDemark, N. L. (1957) Composition of luminal fluids in bovine female genitalia. Fert. Steril. 8, 345.

Osborne, J. C. \& Bourdeau, F. (1955) The stimulated growth of Vibrio fetus by the use of hormones. 7. Bact. 70, 250.

Reich, G. V., Dunne, H. W., Bortree, A. L. \& Hokanson, J. F. (1957) Technique for rapid growth of Vibrio fetus in broth. F. Bact. 74, 246.

Steel, R. G. D. \& Torrie, J. H. (1960) Principles and procedures of statistics. McGraw-Hill, New York.

Trueblood, M. S. \& Tucker, J. O. (1957) An improved method for the cultivation of Vibrio fetus. Am. 7. vet. Res. 18, 445.

Walsh, A. F. \& Whrte, F. H. (1968) Biochemical and serologic characteristics of Vibrio isolants from cattle. Am. F. vet. Res. $29,1377$.

Wilson, G. S. \& MrLes, A. A., Eds. (1964) Topley and Wilson's principles of bacteriology and immunity, 5th edn. Williams \& Wilkins, Baltimore.

Zemjanis, R. \& Hoyt, H. H. (1960) The effect of growth factors on Vibrio fetus. Am. F. vet. Res. 21, 1109. 